\title{
Induced resistance in pepper plants against root knot nematode by some inducers in relation to the histological changes
}

\author{
Mervat E. Sorial ${ }^{1}$, Magdy E. Mahdy ${ }^{1}$, Hanaa S. Zawam², Azhar, A. Aboayana ${ }^{2}$ and E. M. \\ Mousa ${ }^{1}$ \\ 1 Agricultural Botany Department, Faculty of Agriculture, Menoufia University, Shebin El-Kom, Egypt. \\ 2 Plant Pathology Research Institute, Agricultural Research Center, Giza, Egypt.
}

\section{ABSTRACT}

Biochemical and histological studies were made on roots of pepper (Capsicum annuum) infected with root-knot nematode and treated by certain chemical resistance inducers (salicylic acid (SA), indol acetic acid (IAA), ethylene (Eth), Jasmonic acid (JA), in addition to a biofertilizer named (Halex-2). These resistance inducers were tested at three concentrations 100, 200 and $300 \mu \mathrm{M}$ for SA, IAA, and Eth and 15, 20 and $25 \mu \mathrm{M}$ for JA while the biofertilizer was tested at $7 \mathrm{~g} / \mathrm{L}$ as biotic resistance inducers against root-knot nematode Meloidogyne incognita under greenhouse conditions at the Faculty of Agriculture Shebin El-Kom, Menoufia University in season 2016. All concentrations of the tested inducers significantly reduced root-galling and nematode population in soil as well as the number of egg masses and developmental stages per root system. The greatest inhibition effect on reproduction of nematode was recorded with Eth at $300 \mu \mathrm{M}$, which did not significantly differ from that of a nematicide-treated plants. Also, all treatments significantly enhanced all vegetative plant growth characters compared with the infected plants. Biochemical analysis showed a significant increase in the activity of antioxidant enzymes (peroxidase, polyphenoloxidase and catalase), total and reducing sugars, and total phenols at the highest concentration of the tested inducers, especially, Eth compared with the nematode-infested plants. Histological studies indicated that less giant cells were observed in almost all treatments compared to the nematode-infected control plants. However, the highest concentrations of IAA, Eth $(300 \mu \mathrm{M})$ and Halex-2 treatments showed a good performance, with no giant cells found. Sixty days after nematode inoculation, all treatments (except SA and Halex-2) showed a poor formation of regular giant cells divided from cytoplasm and contained less number of nuclei compared to the infected plants. It seems that the tested inducers could be recommended to control $M$. incognita on pepper plants. Thereby, decreases the costs and side effects of using nematicides.

Key words: Capsicum annuum, salicylic acid (SA), indol acetic acid (IAA), ethylene (Eth), Jasmonic acid (JA), Meloidogyne incognita

\section{INTRODUCTION}

Pepper (Capsicum annuum) is one of the most important vegetable crops in Egypt. Most common pepper varieties are susceptible to the southern root-knot nematode $M$. incognita (Ibrahim et al., 2011). Rootknot nematodes are the most economically important nematodes worldwide. Several species of root-knot nematodes are serious pathogens that cause severe damage to major crops. This nematode has been managed by soil fumigants, some chemicals and alternative methods.

The application of salicylic acid (SA), or chemicals with similar action, reduces the root infection by $M$. 
incognita and nematode reproduction (Hari et al., 2011 and Hagag et al., 2016). Treatment of soil with SA clearly improved the control of $M$. Javanica and M.incignita (Naserinasab et al., 2011 and Bakr and Hewedy,2018). Salicylic acid plays an important role in the reduction of parasitism between nematode and plant (Wubben et al., 2007). In many cases, the effect has been explained by the capability of the nematodes to suppress the SA pathway (Uehara et al., 2010 and Shukla et al., 2018).

Foliar application of SA on plants induces a systemic effect that can suppress root knot nematode infection (Selim et al., 2014 and Zebire, 2017). Several complex gene expression and subsequent hormone signaling like JA and SA signaling pathway during incompatible interactions between plants and nematode are considerable aspects to understand the mechanism of resistance.

Jasmonic acid (JA) is a phytohormone with essential role in plant defense against pathogenesis and herbivorous arthropods. (Kazunori et al., 2015). Salicylic acid, JA and ethylene (Eth) regulate the resistance gene mediated and induced defense responses. The signaling of JA and Eth generally showed synergistic interactions while negative pathway may occur between the JA and SA (Bellafiore et al., 2008). Plants have a variety of antioxidant enzymes (e.g. peroxidase, catalase and phenoloxidase) to scavenge excessive reactive oxygen species (ROS) in plant tissue to prevent selfdamage. Moreover, other enzymes superoxide dismutase (SOD) detoxify ROS produced by the plant cell and induce plant resistance (Bellafiore et al., 2008, Ali et al., 2018 and Roze et al., 2008).

Godelieve G. and Melissa G. M. (2019) reported that, application of JA on tomato, rice and soybean invariably reduces root-knot nematode (RKN) infection (Cooper et al., 2005; Nahar et al., 2011 and kyndt et al., 2017), while inhibitors of JA biosynthesis enhance infection (Nahar et al., 2011 and Zhao et al., 2015). Davies (2010) reported that Eth probably having a restraining role by activating nematode repellents and JA, biosynthesis, facilitating radial expansion of the giant cells. Ethylene and auxin are important plant hormones involved in the regulation of many important plant processes. For instance, cell differentiation, cell expansion and responses of plant to biotic stresses. Nahar et al. (2011) and Mantelin et al. (2013) cited that Eth inhibits RKN infection, possibly through a decrease in nematode attraction to the roots. Consistent with Eth playing a role in plant defense to RKN infection, resistant plants showed more upregulation of Eth biosynthesis and response genes than susceptible plants (Kumari et al., 2016 and Shukla et al ., 2018).

Grunewald et al. (2009) found that, auxin manipulation is well-known to be an important process during initiation and easily development of highly specialized feeding sites (NFS) of sedentary plant parasitic nematodes. Auxin is known for its role in cell expansion via the up-regulation of cell wall modifying proteins and plasma membrane proton pumps that regulate acid growth (Majda and Robert, 2018). Jasmonic acid and SA are the principal plant defense hormones and can have different effects depending on the specific host-nematode interaction, nematodes have evolved plant peptide hormone effect or mimics to facilitate parasitism. Mur et al. (2006). Ali et al. (2013) reported that the Ethresponsive RAP 2.6 gene is down regulated in syncytia and its over expression leads to enhanced resistance which the authors suggest is 
a result of activated JA pathway. Yuan et al., (2016) reported that, auxin and Eth cooperatively lead to the development of cell wall during transfer cell formation.

$\mathrm{Li}$ et al., (2006) reported that three biological compounds including SA, JA and Eth regulate the resistance gene inducing basal defense responses. Plant hormones like Eth and JA have the ability to interfere with tomato SA inducible potato cyst nematode (PCN) resistance pathway in susceptible cultivars (Uehara et al., 2010).Nahas et al., (2011) and Fudali et al., (2013) reported that treating tomato plants by Eth inhibited gall development and giant cells. Nina et al., (2015) suggested that there is a positive role of Eth during nematode attraction, whereas JA triggers early defense responses against $H$. schachtii. Salicylic acid seems to be a negative regulator during female development.

The objective of the present study was to determine the ability of some inducers i.e. SA, JA, indol acetic acid (IAA), Eth and a biofertilizer) to induce systemic resistance in pepper plants against the root-knot nematode $M$. incognita, with a special reference to biochemical changes in antioxidant enzymes, sugars, phenols as well as root histology.

\section{MATERIALS AND METHODS}

Plastic pots (30-cm-diam.) were filled with $7 \mathrm{~kg}$ sandy-loam soil (2:1; $\mathrm{v} / \mathrm{v})$. Seedlings were dipped into solutions of SA, IAA, JA and Eth at three concentrations, 100, 200 and 300 $\mu \mathrm{M}$ for SA and IAA;15, 20 and $25 \mu \mathrm{M}$ for $\mathrm{JA}$, and $7 \mathrm{~g} / \mathrm{L}$ for a biofertilizer named (Halex-2) [which contains a mixture of growth promoting $\mathrm{N}_{2}$-fixing bacteria of genera Azospirillum, Azotobacter and klebsiella, which was supplied by the Biofertilization Unit, Plant Pathology Dept., Alexandria
University], for two hours before planting and then applied as a soil drench by drenching $20 \mathrm{ml} /$ plant of each inducer concentration once every two days for two weeks. Three days after treatment, seedlings were inoculated with 5000 second-stage juveniles (J2s) of $M$. incognita/individual seedling (one seedling/pot). Three pots inoculated with $5000 \mathrm{~J} 2 \mathrm{~s}$ in tap water served as a control (Sahebani and Hadavi, 2009). Each treatment was replicated three times, with seedlings soaked and drenched with tap water served as control. Three pots treated with the nematicide vydate at 0.3 $\mathrm{ml} /$ plant served as a positive control. Pots were randomly arranged on a greenhouse bench at $25 \pm 2^{\circ} \mathrm{C}$, and watered as needed. Sixty days after nematode inoculation, plants were uprooted and number of galls, egg masses, and developmental stages were recorded per root, and J2 was counted per $250 \mathrm{~g}$ soil. Final population and reproduction factor (RF) were calculated according to the equation: $\mathrm{RF}=\mathrm{Pf}$ (final population) / $\mathrm{Pi}$ (initial population) (Sasser et al., 1984). Plant growth parameters i.e. fresh shoot and root weights $(\mathrm{g})$, dry shoot weight $(\mathrm{g})$, shoot and root length $(\mathrm{cm})$ were also recorded. Data of chemical analysis were recorded, namely antioxidant enzymes activity (peroxidase, polyphenoloxidase, and catalase), total and reducing sugars, and total and free phenols. Histological studies were also conducted in roots.

\section{Physiological and biochemical analysis:}

\section{Antioxidant enzymes activity}

Crude enzyme extracts of peroxidase and polyphenoloxidase were prepared according to Aluko and Ogbadu (1986). One gram of the homogenized pepper fresh leaves was extracted with $3 \mathrm{ml}$ of $0.1 \mathrm{M}$ phosphate buffer $(\mathrm{pH} 7)$. The homogenate was 
filtered and then centrifuged at 3000 rpm for $15 \mathrm{~min}$. at $4^{\circ} \mathrm{C}$. The supernatant filtered and collected as an enzyme extract. Enzyme extracts were stored at $2-5^{\circ} \mathrm{C}$ and aliquots of these were assayed for enzymes activity using Milton Roy Spectronic 601 spectrophotometer. Enzymes activity were determined as follows:

\section{A) Peroxidase}

Peroxidase activity was determined according to the method of Fehrman and Dimond (1967). The increase in absorbance was determined using spectrophotometer (Milton Roy Spectronic 601) at $430 \mathrm{~nm}$ from $60-120$ second after substrate was added. Peroxidase activity was expressed as O.D/g fresh weight (fw)/min.

\section{B) Polyphenoloxidase}

Polyphenoloxidase activity was measured following the method described by Broesh (1954). The enzyme activity was measured as the change in absorbance after 45 minutes at $495 \mathrm{~nm}$ and expressed as O.D./g $\mathrm{fw} / 45 \mathrm{~min}$.

\section{C) Catalase}

Catalase activity was determined as described by Bach and Oparin (1968). The decomposition of $\mathrm{H}_{2} \mathrm{O}_{2}$ was measured by titration of the remaining substrate with $0.0052 \mathrm{~N}$ potassium permanganate after stopping the enzymatic reactions with $5 \mathrm{ml}$ of $2 \%$ $(\mathrm{v} / \mathrm{v})$ sulphoric acid and the readings were replaced in a standard equation to find the final results.

\section{Sugars and phenols determination}

\section{Sample preparation}

Fresh plant sample $(10 \mathrm{~g})$ from each replicate of each treatment was cut into small pieces and immediately macerated into $95 \%$ boiling ethanol for $10 \mathrm{~min}$. The macerated samples were transferred into soxhlet unites containing $75 \%$ ethanol as an extraction solvent. The extract process resumed for $12 \mathrm{hr}$. Ethanol extracts were filtrated and evaporated until the complete removal of ethanol. The dried residue was dissolved in $5 \mathrm{ml}$ isopropanol $50 \%$ and kept in freezer till analysis. The extracts were used later for analysis of sugars and phenols.

\section{A) Total and reducing sugars}

Total soluble sugars and reducing sugars were spectrophotometric determined using the picric acid technique as described by Thomas and Dutcher (1924). A volume of $0.5 \mathrm{ml}$ of each extract was placed in a test tube; containing $5 \mathrm{ml}$ of distilled water and 4 $\mathrm{ml}$ picric solution were added. The mixture was boiled for $10 \mathrm{~min}$. After cooling, $1 \mathrm{ml}$ sodium carbonate solution (20\%) was added and the mixture was boiled again for $15 \mathrm{~min}$. After which, it was cooled and the tubes were completed to $10 \mathrm{ml}$ with distilled water. Thereafter, the density of developed color was determined at $540 \mathrm{~nm}$ using spectrophotometer (Milton Roy Spectronic 601) in presence of a blank and using glucose as a standard.

\section{Reducing sugars}

The same described procedure for total sugars was used except that the picric- and sodium carbonate-solutions were added together at the same time. The same spectrophotometer and wavelength were used. Sugars concentration was expressed as $\mathrm{mg} / \mathrm{g}$ fw.

\section{B. Phenol compounds (Total and Free phenols)}

Total phenols was determined as described by Simons and Ross (1971). Concentrate hydrochloric acid $(0.25 \mathrm{ml})$ was added to $0.2 \mathrm{ml}$ of the sample extract in a test tube and mixed. The mixture was then boiled for about 10 min. After cooling, $1 \mathrm{ml}$ Folin reagent 
and $5 \mathrm{ml}$ sodium carbonate solution $(20 \%)$ were added and diluted to $10 \mathrm{ml}$ using distilled water. After 30 min., the density of the developed blue color was determined at $520 \mathrm{~nm}$ using catechol as a standard.

Free phenols were determined using the same described method with some exception, since $1 \mathrm{ml}$ Folin reagent and $3 \mathrm{ml}$ sodium carbonate solution (20\%) were added to $0.2 \mathrm{ml}$ of the sample extract, diluted with distilled water to $10 \mathrm{ml}$. After $30 \mathrm{~min}$., the density of the developed blue color was determined at same wavelength. Total and free phenols concentration was measured as $\mathrm{mg} / \mathrm{g} \mathrm{fw}$.

\section{Histological studies}

Samples for anatomical studies were taken from nematode-infected roots of each treatment, at 60 days from nematode inoculation. Samples were cut into suitable pieces not more than $5-\mathrm{mm}$ thick in order to facilitate the exchanges of different solutions. Samples were placed in formalin-ethyl alcohol-acetic acid (F.A.A.) for 36-48 hr and samples were washed by tap water, then dehydrated using ascending concentrations of ethyl alcohol. Before infiltration, samples were passed into increasing concentrations of xylol in absolute alcohol. Infiltration was completed in oven when pure melted wax was added. Samples were embedded in paraffin wax (O'Brien and Mccully, 1981). Sections were microtomed at 15 micron and the combination of safraninlight green stain was used. Photomicrography was obtained histometry in order to observe the areas of different tissues, and good transverse sections were drawn by means of camera lucida.

\section{Statistical analysis}

The collected data were subjected to statistical analysis using the F-test and means were compared by LSD at level of probability as described by (Snedecor and Cochran 1972) and using (Costat software 1985).

\section{RESULTS}

Data presented in Table (1) show that all the tested abiotic inducers were effective in reducing the nematode root galling and inhibiting the nematode reproduction on pepper. All tested concentrations reduced all the related nematode parameters. The positive effect of such treatments was increased as dosage of the inducers increased. The highest concentration of Eth $(300 \mu \mathrm{M})$ was the most effective one, followed by SA, biofertilizer, IAA, and $\mathrm{JA}$ in reducing the root galling, number of juveniles in soil as well as number of egg-masses and developmental stage/root system. The lowest reduction was obtained by the lowest concentration of JA $(15 \mu \mathrm{M})$ compared to plants treated with nematode alone. Results also show that the highest concentration of all inducers were the most effective in reducing the nematode population and reproduction factor compared to the other two concentrations as shown in Table (1) and Fig. (1).

Data in Table (2) showed that treating pepper plants with abiotic and biotic inducers significantly enhanced all vegetative plant growth characters, i.e., fresh shoot and root weight (g), dry shoot weight (g), plant height and root length $(\mathrm{cm})$ compared with the untreated control plants. The greatest effect was recorded with the application of Eth at $200 \mu \mathrm{M}$, followed by the highest concentration of JA, SA, IAA and biofertilizer. On the other hand, the lowest effect was recorded with the lowest concentrations of the inducers compared with plants treated with nematode alone. 

Table (1): Effect of certain abiotic and biotic inducers for management of Meloidogyne incognita in pepper plants.

\begin{tabular}{|c|c|c|c|c|c|c|c|}
\hline Treatment & $\begin{array}{l}\text { Conc. } \\
(\mu \mathrm{M})\end{array}$ & $\begin{array}{l}\text { Galls/ } \\
\text { root } \\
\text { system }\end{array}$ & $\begin{array}{c}\text { Egg } \\
\text { masses/ro } \\
\text { ot system }\end{array}$ & $\begin{array}{c}\mathrm{J} 2 / 250 \mathrm{~g} \\
\text { soil }\end{array}$ & $\begin{array}{l}\text { Developmental } \\
\text { stages/root } \\
\text { system }\end{array}$ & $\begin{array}{c}\text { Final } \\
\text { population } \\
\text { (PF) }\end{array}$ & $\begin{array}{l}\text { Reproduction } \\
\text { factor } \\
\text { (RF) }\end{array}$ \\
\hline Salicylic acid & $\begin{array}{l}100 \\
200 \\
300\end{array}$ & $\begin{array}{l}8 \\
7 \\
5\end{array}$ & $\begin{array}{l}9 \\
5 \\
2\end{array}$ & $\begin{array}{l}68 \\
48 \\
11\end{array}$ & $\begin{array}{c}17 \\
6 \\
4\end{array}$ & $\begin{array}{c}102 \\
66 \\
22\end{array}$ & $\begin{array}{l}0.020 \\
0.013 \\
0.004\end{array}$ \\
\hline Jasmonic acid & $\begin{array}{l}15 \\
20 \\
25\end{array}$ & $\begin{array}{l}37 \\
14 \\
13\end{array}$ & $\begin{array}{l}19 \\
11 \\
7\end{array}$ & $\begin{array}{l}91 \\
56 \\
14\end{array}$ & $\begin{array}{l}26 \\
18 \\
6\end{array}$ & $\begin{array}{c}173 \\
99 \\
40\end{array}$ & $\begin{array}{l}0.034 \\
0.019 \\
0.008\end{array}$ \\
\hline Indol acetic acid & $\begin{array}{l}100 \\
200 \\
300 \\
\\
100\end{array}$ & $\begin{array}{c}17 \\
10 \\
9\end{array}$ & $\begin{array}{c}15 \\
9 \\
5\end{array}$ & $\begin{array}{l}93 \\
65 \\
54\end{array}$ & $\begin{array}{l}45 \\
33 \\
10\end{array}$ & $\begin{array}{c}170 \\
117 \\
78\end{array}$ & $\begin{array}{l}0.034 \\
0.023 \\
0.015\end{array}$ \\
\hline Ethylene & $\begin{array}{l}200 \\
300\end{array}$ & $\begin{array}{c}13 \\
3 \\
1\end{array}$ & $\begin{array}{c}11 \\
7 \\
2\end{array}$ & $\begin{array}{l}50 \\
43 \\
17\end{array}$ & $\begin{array}{c}21 \\
13 \\
7\end{array}$ & $\begin{array}{l}95 \\
66 \\
27\end{array}$ & $\begin{array}{l}0.019 \\
0.013 \\
0.005\end{array}$ \\
\hline $\begin{array}{l}\text { Biofertilizer } \\
\text { (Halex-2) } \\
\text { Vydate }\end{array}$ & $\begin{array}{c}7 \mathrm{~g} / \mathrm{L} \\
0.3 \mathrm{ml} /\end{array}$ & $\begin{array}{l}8 \\
5\end{array}$ & $\begin{array}{l}6 \\
4\end{array}$ & $\begin{array}{l}130 \\
72\end{array}$ & $\begin{array}{l}39 \\
9\end{array}$ & $\begin{array}{l}183 \\
90\end{array}$ & $\begin{array}{l}0.036 \\
0.018\end{array}$ \\
\hline $\begin{array}{l}\text { Nematode } \\
\text { alone } \\
\text { LSD5\% }\end{array}$ & prálit & $\begin{array}{c}114 \\
1.254\end{array}$ & $\begin{array}{c}98 \\
2.103\end{array}$ & $\begin{array}{r}483 \\
11.04\end{array}$ & $\begin{array}{l}212 \\
2.11\end{array}$ & 907 & $\begin{array}{c}0.181 \\
-\end{array}$ \\
\hline
\end{tabular}

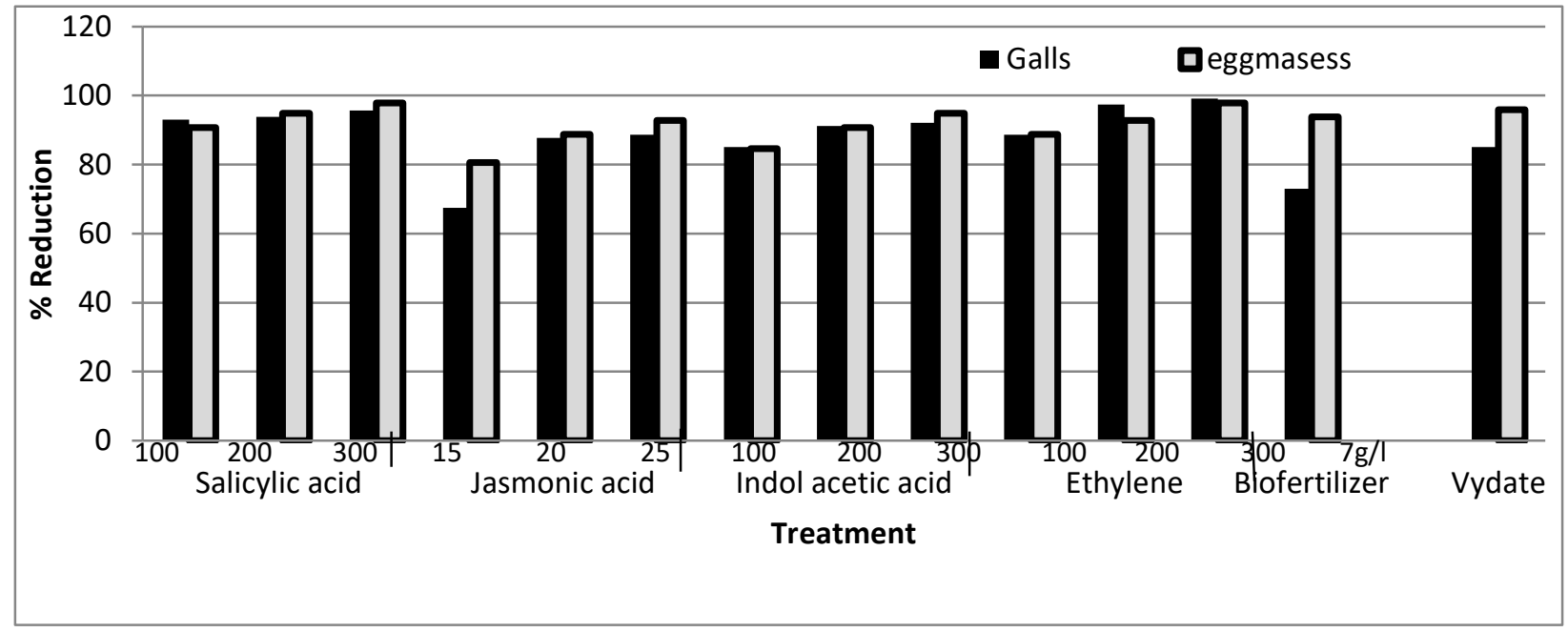

Fig.1A: Effect of certain abiotic and biotic inducers at different concentrations on the reduction of galls, egg masses /root system. 


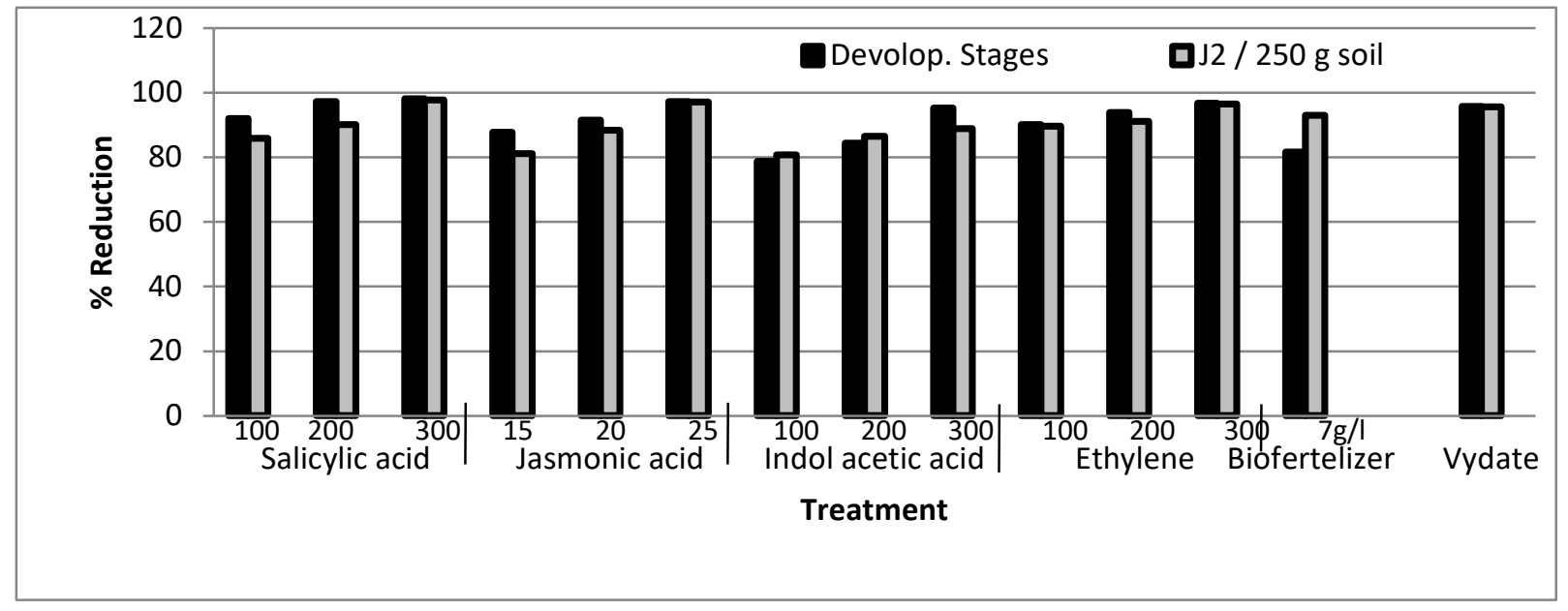

Fig.1B: Effect of certain abiotic and biotic inducers at different concentrations on the reduction of developmental stages /root system and J2/250 g soil.

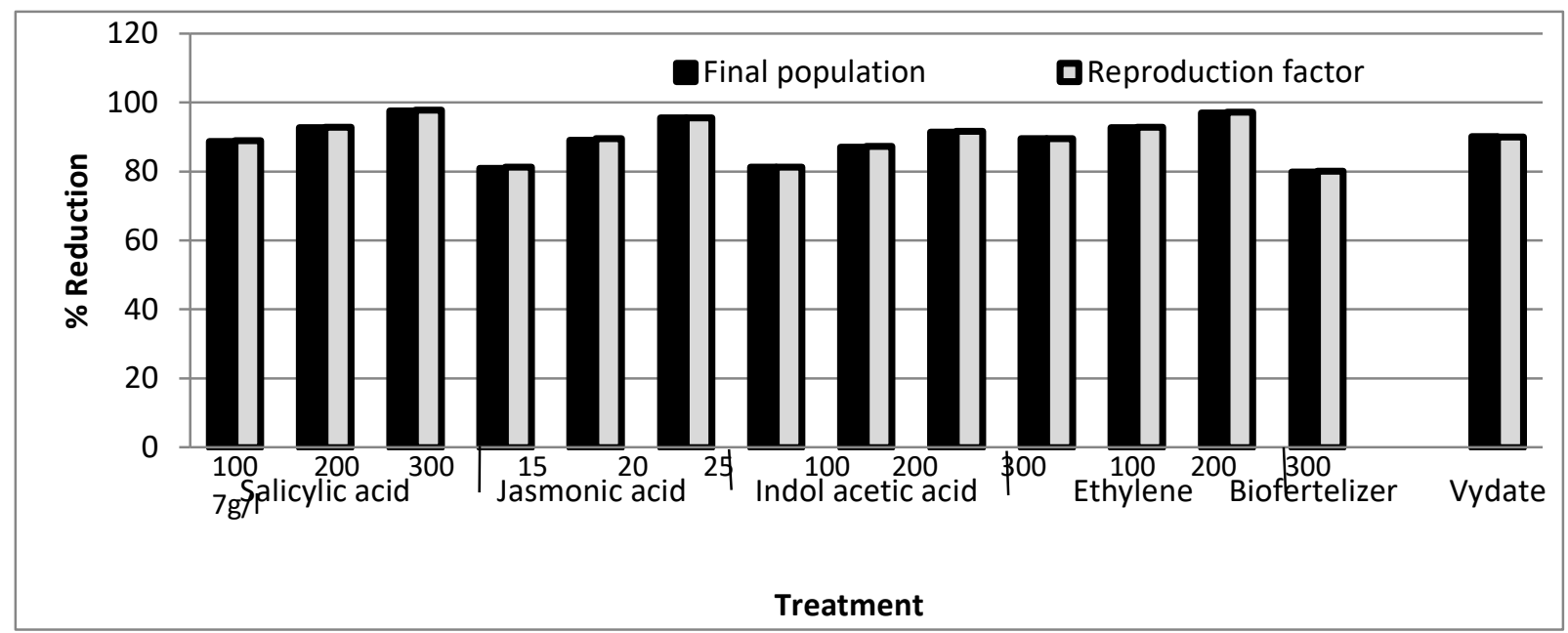

Fig.1C: Effect of certain abiotic and biotic inducers at different concentrations on the reduction of final population and reproduction factor.

Table (2): Effect of certain abiotic and biotic inducers on growth characters of pepper plants infected with Meloidogyne incognita.

\begin{tabular}{|c|c|c|c|c|c|c|}
\hline Treatment & $\begin{array}{l}\text { Conc. } \\
(\mu \mathrm{M})\end{array}$ & $\begin{array}{c}\text { Fresh } \\
\text { shoot weight } \\
\text { (g) }\end{array}$ & $\begin{array}{c}\text { Fresh Root } \\
\text { weight } \\
\text { (g) }\end{array}$ & $\begin{array}{c}\text { Dry } \\
\text { shoot weight } \\
\text { (g) }\end{array}$ & $\begin{array}{l}\text { Shoot } \\
\text { length } \\
(\mathrm{cm})\end{array}$ & $\begin{array}{l}\text { Root } \\
\text { length } \\
\text { (cm) }\end{array}$ \\
\hline Salicylic acid & $\begin{array}{l}100 \\
200 \\
300\end{array}$ & $\begin{array}{c}8.3 \\
9.8 \\
10.8\end{array}$ & $\begin{array}{l}2.0 \\
2.1 \\
2.4\end{array}$ & $\begin{array}{l}1.8 \\
2.0 \\
2.1\end{array}$ & $\begin{array}{l}31.3 \\
32.0 \\
33.0\end{array}$ & $\begin{array}{c}8.5 \\
9.0 \\
11.3\end{array}$ \\
\hline Jasmonic acid & $\begin{array}{l}10 \\
15 \\
25\end{array}$ & $\begin{array}{c}7.2 \\
10.2 \\
11.7\end{array}$ & $\begin{array}{l}2.4 \\
2.6 \\
2.7\end{array}$ & $\begin{array}{l}2.1 \\
2.2 \\
2.7\end{array}$ & $\begin{array}{l}34.6 \\
37.3 \\
39.3\end{array}$ & $\begin{array}{l}9.0 \\
8.6 \\
8.6\end{array}$ \\
\hline Indol acetic acid & $\begin{array}{l}100 \\
200 \\
300\end{array}$ & $\begin{array}{c}8.3 \\
9.8 \\
10.8\end{array}$ & $\begin{array}{l}2.2 \\
2.8 \\
3.3\end{array}$ & $\begin{array}{l}2.0 \\
2.1 \\
2.5\end{array}$ & $\begin{array}{l}30.6 \\
32.6 \\
35.0\end{array}$ & $\begin{array}{l}10.3 \\
11.6 \\
13.3\end{array}$ \\
\hline Ethylene & $\begin{array}{l}100 \\
200 \\
300\end{array}$ & $\begin{array}{l}12.5 \\
15.5 \\
13.7\end{array}$ & $\begin{array}{l}3.1 \\
3.9 \\
2.3\end{array}$ & $\begin{array}{l}2.6 \\
3.1 \\
2.8\end{array}$ & $\begin{array}{l}37.6 \\
42.3 \\
39.6\end{array}$ & $\begin{array}{c}9.0 \\
10.0 \\
12.0\end{array}$ \\
\hline Biofertilizer (Halex-2) & $7 \mathrm{~g} / \mathrm{L}$ & 13.4 & 2.9 & 2.5 & 36.3 & 11.5 \\
\hline Vydate (nematicide) & $\begin{array}{c}0.3 \mathrm{ml} / \mathrm{pl} \\
\text { ant }\end{array}$ & 11.7 & 2.2 & 2.1 & 29.3 & 8.3 \\
\hline Nematode alone & & 7.4 & 3.3 & 1.6 & 20.6 & 7.0 \\
\hline Healthy plants & & 11.3 & 3.5 & 2.4 & 34.6 & 10.8 \\
\hline LSD5\% & & 0.166 & 0.726 & 0.412 & 2.064 & 0.066 \\
\hline
\end{tabular}


The effect of adding the inducers at different concentrations on antioxidant enzyme activity of pepper plant treated with the root-knot nematode $M$. incognita is given in Fig. (2). It can be illustrated that IAA and Eth at $300 \mu \mathrm{M}$ significantly increased PO compared to healthy plants. The best treatment in increasing $\mathrm{PO}$ and PPO activity was $300 \mu \mathrm{M}$ of Ethylene, flowed by SA, IAA, and Biofertilizer. However, the least increase in enzymes activity was obtained by $15 \mu \mathrm{M}$ of JA. On the other hand, Eth. at $300 \mu \mathrm{M}$ was the best treatment in increasing the activity of catalase.

Data presented in Fig. (3) recorded the effect of some abiotic and biotic inducers on reducing sugars content in pepper plants. It can be concluded that all treatments under study significantly increased sugar content. The most effective treatment in increasing the total and reducing sugars was Eth at $300 \mu \mathrm{M}$, and $\mathrm{JA}$ at $25 \mu \mathrm{M}$. However, the least sugar content was recorded in the nematode-alone treated plants. Data presented in Fig. (4) showed the effect of some inducers on phenol content in pepper plants. It was found that all treatments significantly increased phenols content. The highest effective treatment in increasing the total and free phenols was Eth and SA at $300 \mu \mathrm{M}$. The lowest level of total and free phenol concentrations was recorded in nematode-alone treated plants.

\section{Histological studies}

Treated and untreated infected pepper roots were processed for histological examination via making transverse sections, 60 days after nematode inoculation using a microscope. It can be noticed that $M$. incognita induced alterations in cells of cortical and the main region in pepper roots (Fig. 5). Giant cells were found prolonged in vascular parenchyma cells with different shapes from circular to irregular shape. Clusters were present as a result of forming giant cells and the growth of the nematode females. Moreover, it can be recognized the hypertrophied nuclei were aggregated in the cytoplasm with number ranged from 13-15 and induced more disruption in xylem and cortex layers (Fig. 5).

As for histological alterations in pepper plant infected with root knot nematode $M$. incognita but treated with SA $(300 \mu \mathrm{M})$, the number of giant cells was less than that in the control (treatment of nematode alone) 60 days after nematode inoculation, which ranged from 8-10 with less numbers of hypertrophy and disruption in xylem and cortex layers as a result of presence of giant cells (Fig. 6).

Regarding the effect of $\mathrm{JA}$ at $25 \mu \mathrm{M}$, after 60 days from nematode inoculation, it was found about 4-5 irregular shape cells and hypertrophied nuclei cells (Fig. 7). Pepper plants infected with nematode and treated with IAA at $300 \mu \mathrm{M}$ showed better performance at 60 days after nematode inoculation, it can be noticed that giant cells formed in feeding sites and disruption in xylem and cortex layers as a result of the presence of less number of giant cells and growing female nematodes (Fig. 8). It can be noticed also, root transverses section become irregular due to inducing compressed cells. In this concentration it can be noticed that pepper plants infected with nematode and treated with Eth at $300 \mu \mathrm{M}$ after 60 days from nematode inoculation did not show any giant 
cells and the root section almost similar to that of the healthy control plants (Fig. 9 \& Table 2). The root transverse sections of pepper plants infected with nematodes and treated by the biofertilizer Halex-2 at $7 \mathrm{~g} / \mathrm{L}$ showed were similar to those less number of giant cells (ranged from 23) (Fig.10).
Infected roots of pepper plants with nematode $M$. incognita and treated with nematicide vaydate showed a poor formation and irregular giant cells divided from cytoplasm and contained less number of nuclei (Fig. 11) compared to the healthy plants (Fig.

12).

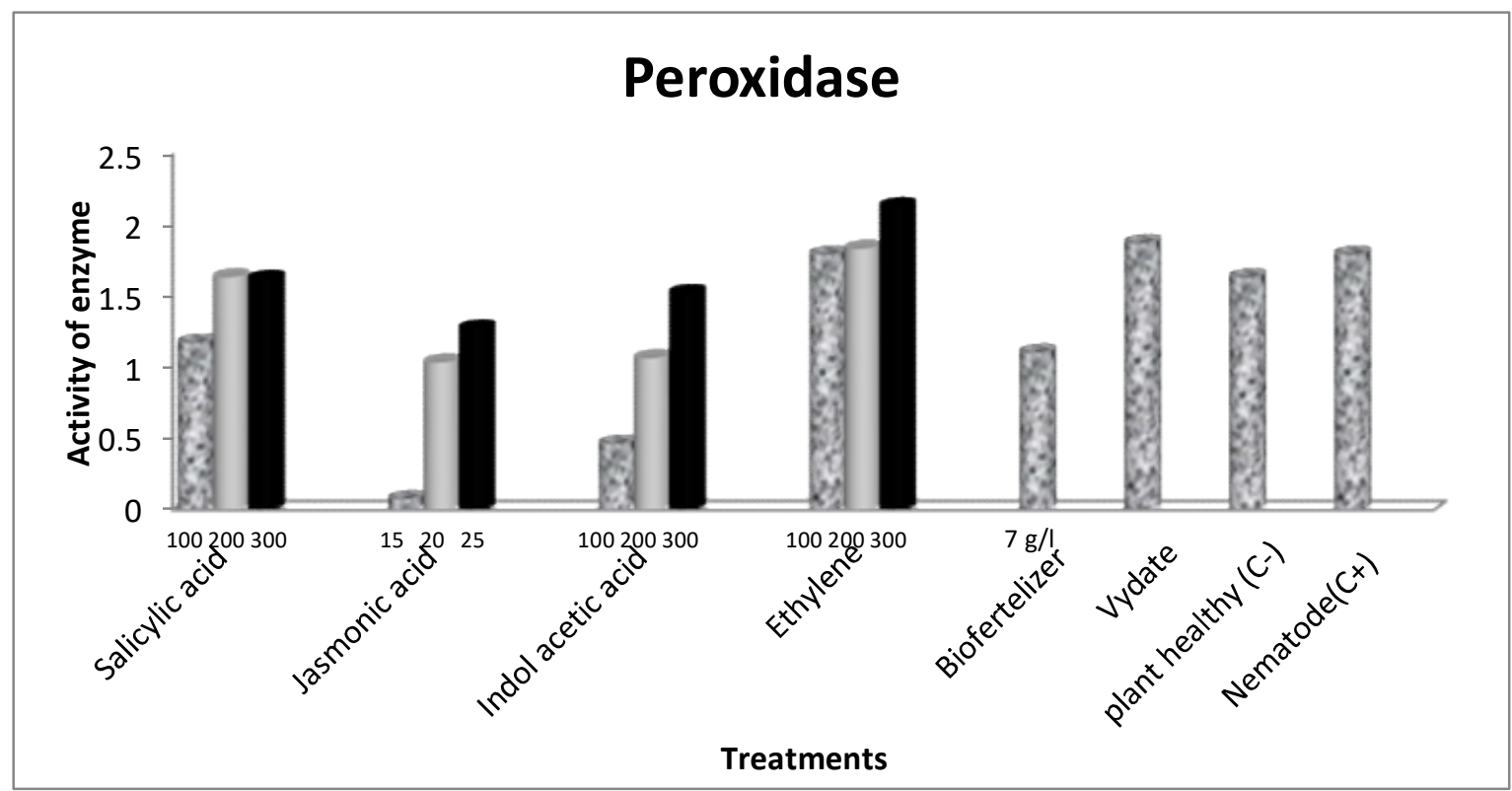

Fig. 2 (A ): Effect of certain abiotic and biotic inducers on peroxidase enzyme activity of pepper plants infected with Meloidogyne incognita.

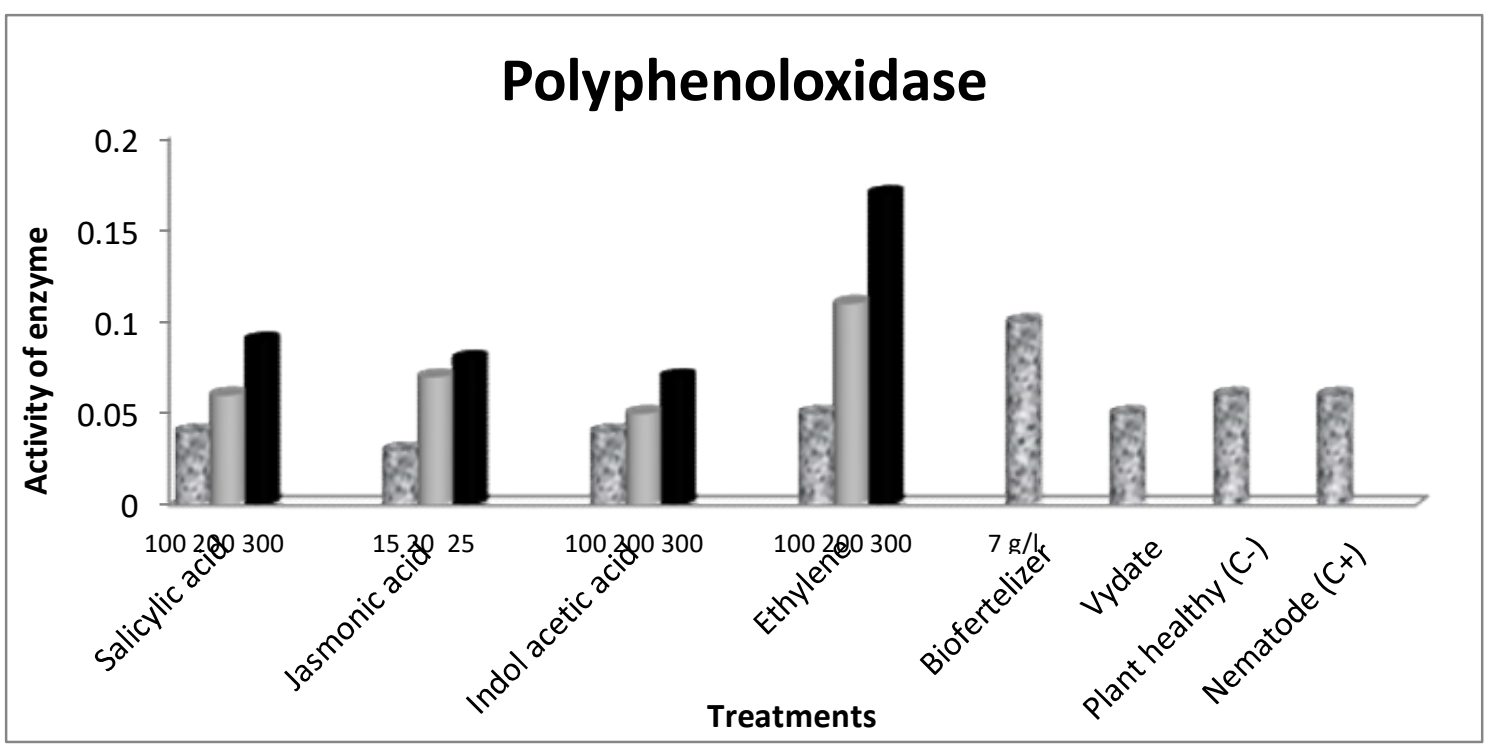

Fig. 2 (B): Effect of certain abiotic and biotic inducers on polyphenoloxidase enzyme activity of pepper plants infected with Meloidogyne incognita. 


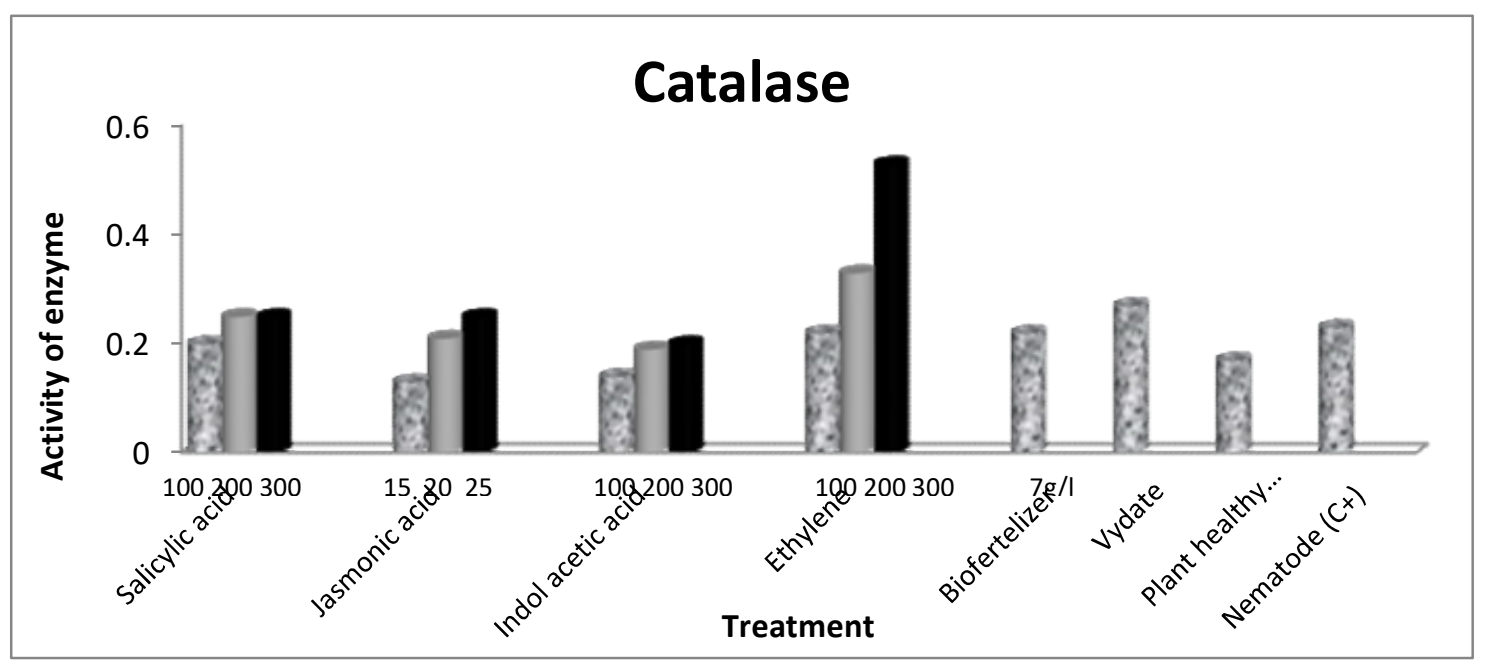

Fig. 2 (C): Effect of certain abiotic and biotic inducers on catalase enzyme activity of pepper plants infected with Meloidogyne incognita

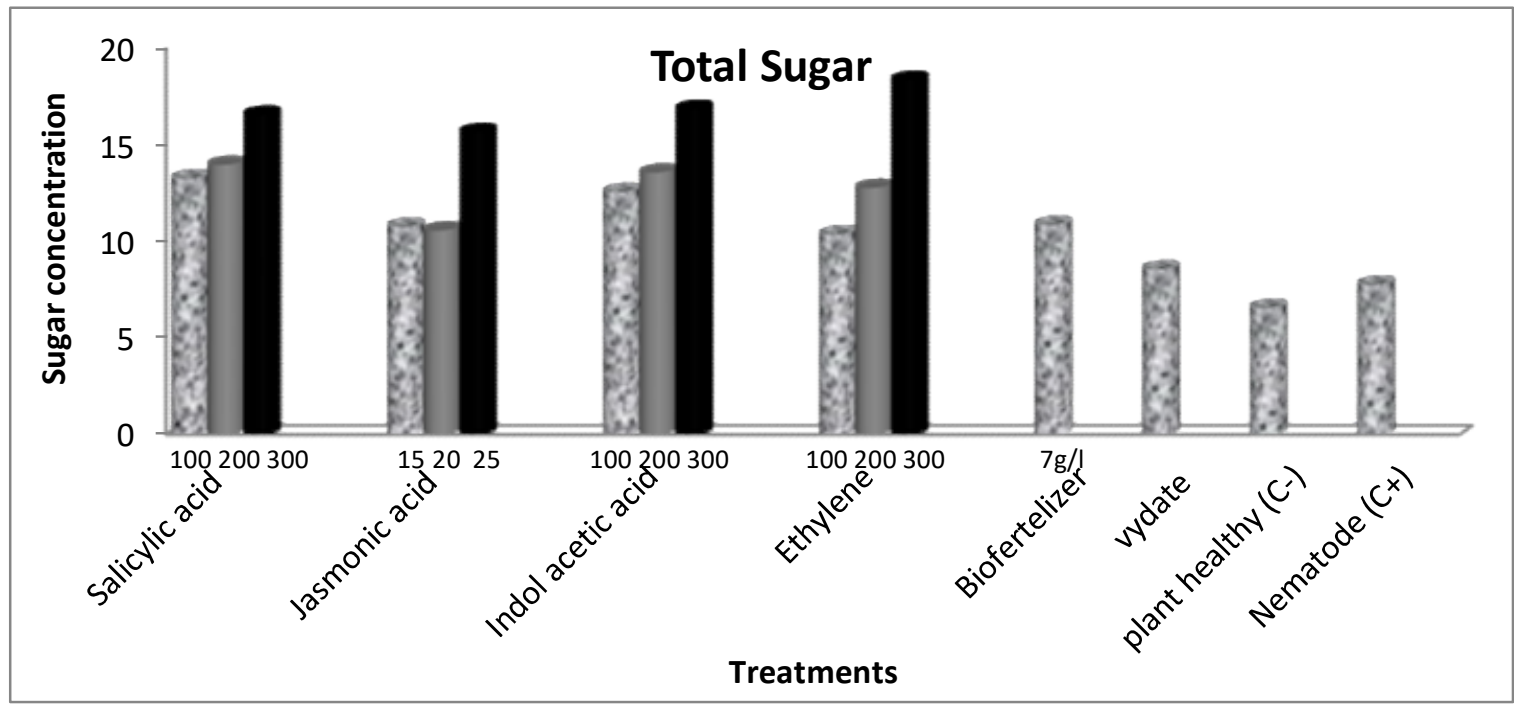

Fig. 3 (A): Effect of certain abiotic and biotic inducers on total sugar content of pepper plants infected with Meloidogyne incognita.

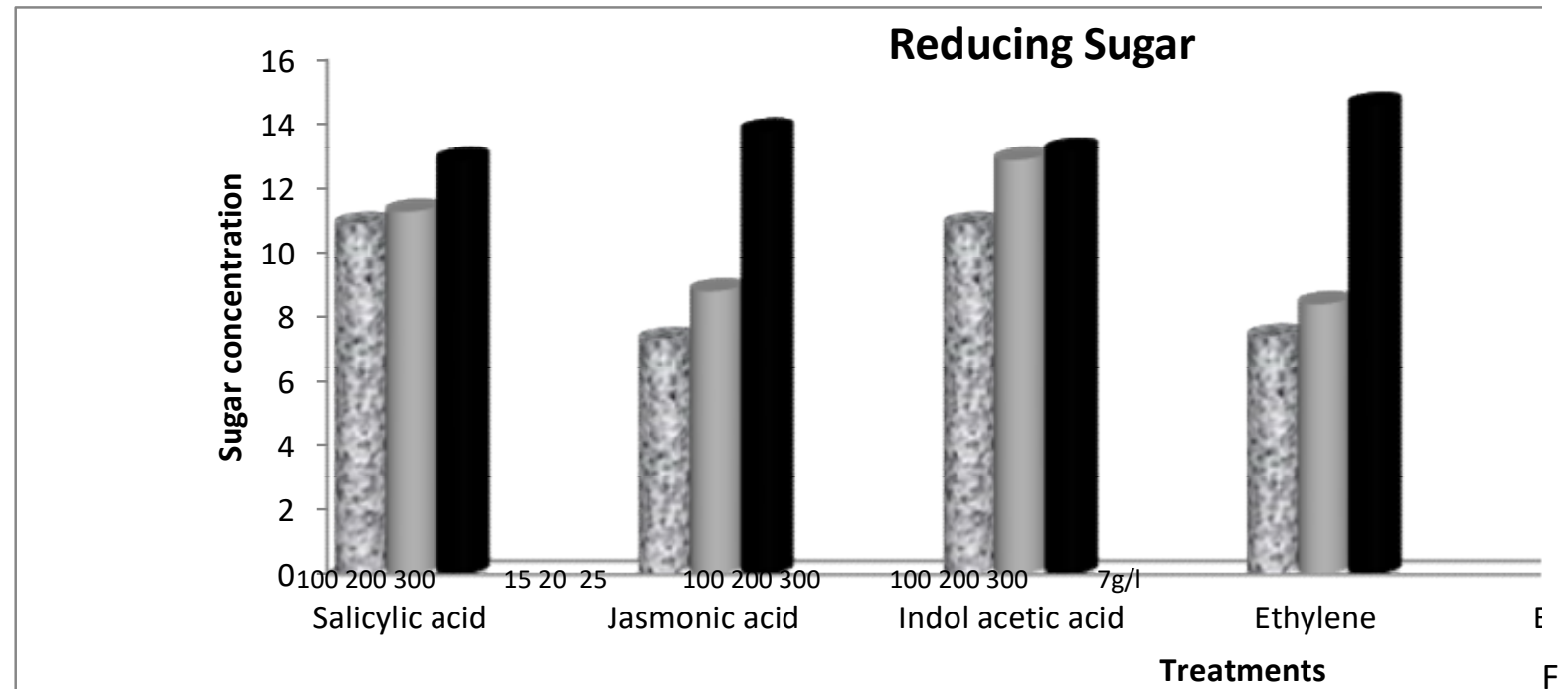

ig. 3 ( B): Effect of certain abiotic and biotic inducers on sugar content of pepper plants infected with Meloidogyne incognita. 


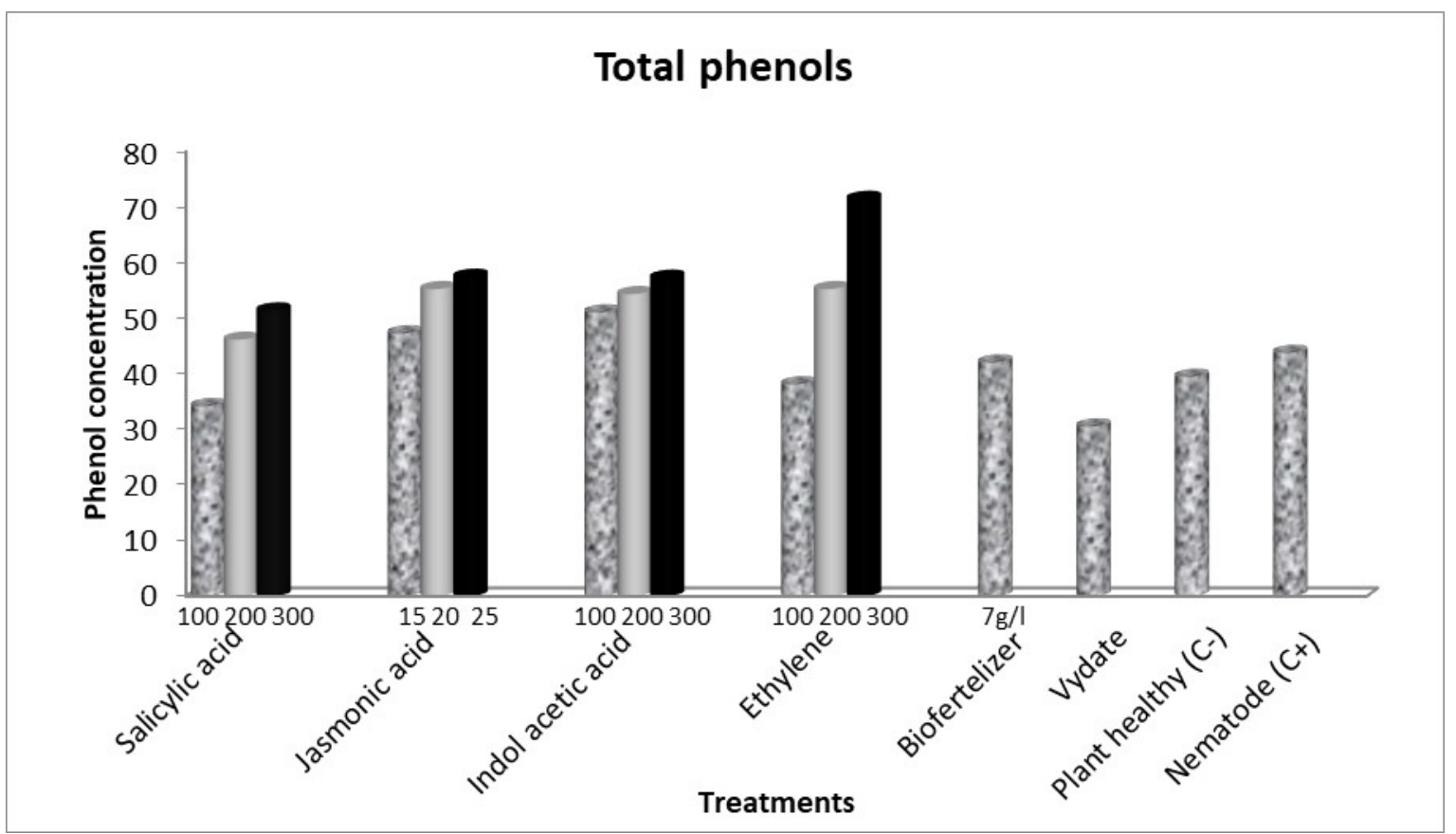

Fig. 4 (A \& B): Effect of certain abiotic and biotic inducers on total phenols concentrations in pepper plants infected with Meloidogyne incognita.

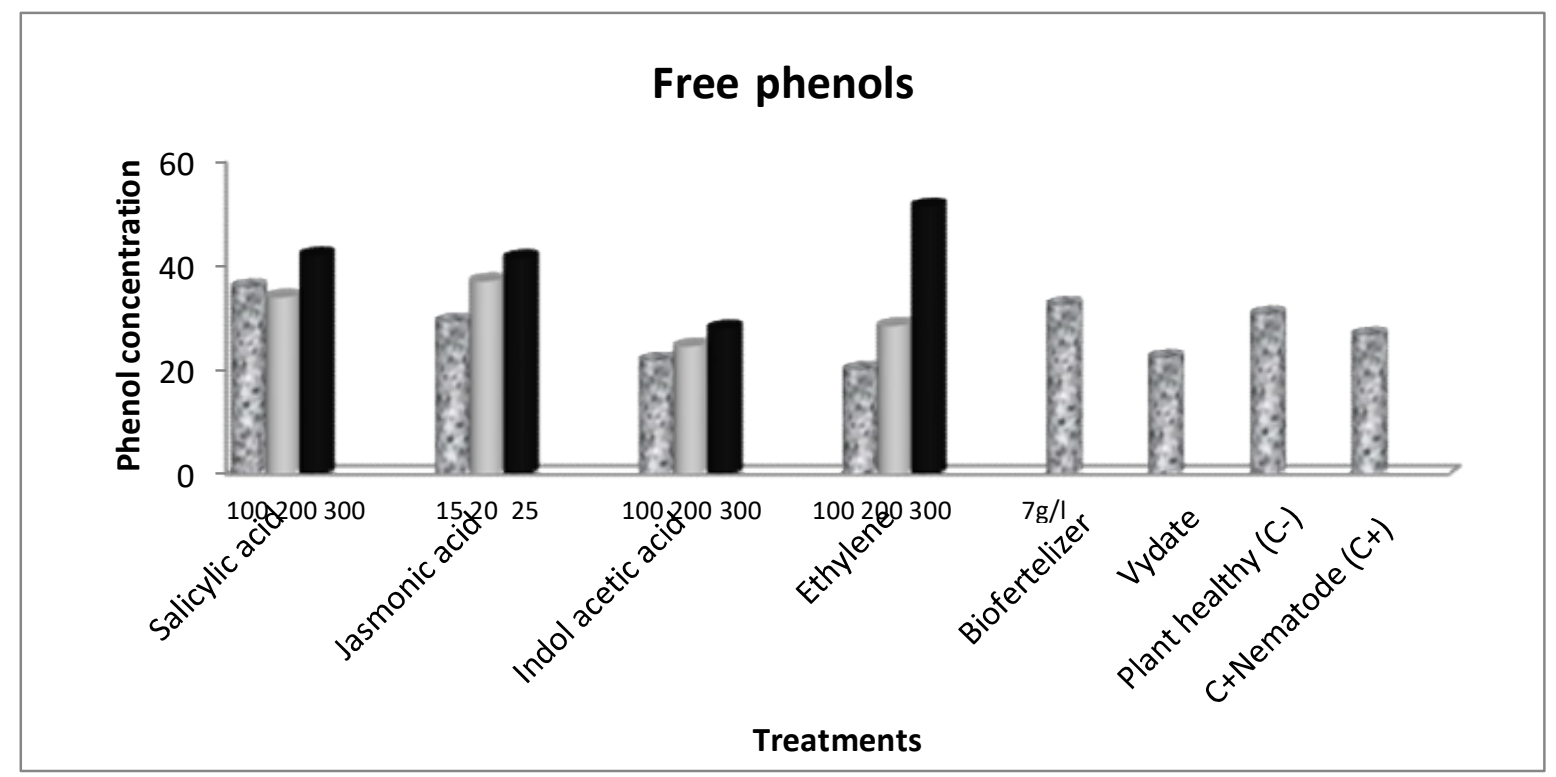

Fig. 4 (A \& B): Effect of certain abiotic and biotic inducers on free phenols concentrations in pepper plants infected with Meloidogyne incognita.

\section{DISCUSSION}

All inducers used in this experiment have reduced nematode population at all concentrations used. This finding may refer to understanding that phytohormone involvement in the establishment and maintenance of the feeding site is critical to the development.

During nematode infection, the preparasitic second stage juveniles (J2) penetrate the roots of a suitable host, then migrate intercellularly towards the vascular cylinder to find a competent 
plant cell for the induction of multinuclear feeding cell complex.

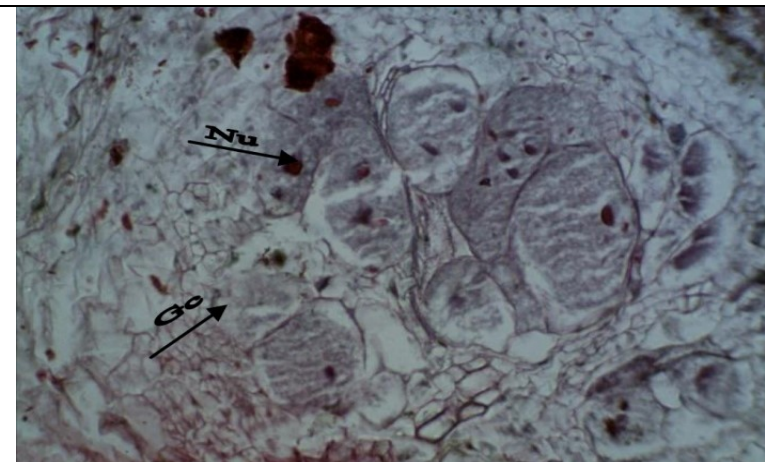

Fig. (5): Root transverse section of pepper plants infected with $M$. incognita.

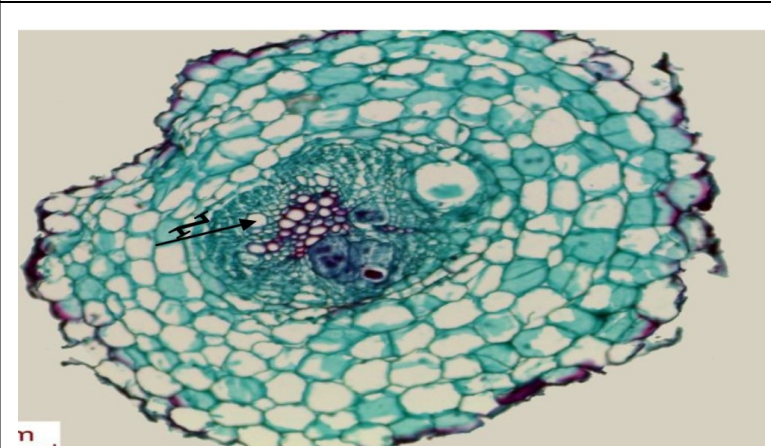

Fig. (7): Root transverse section of pepper plants infected with $M$.incognita and treated with JA $(25 \mu \mathrm{M})$.

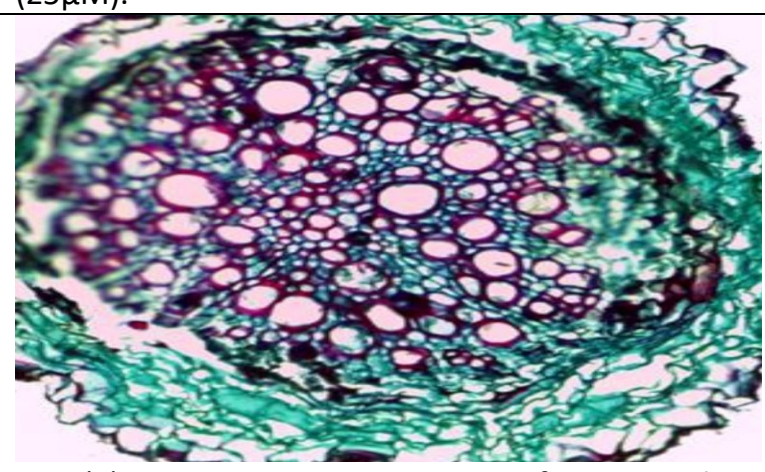

Fig. (9): Root transverse section of pepper plants infected with $M$. incognita and treated with ethylene $(300 \mu \mathrm{M})$.

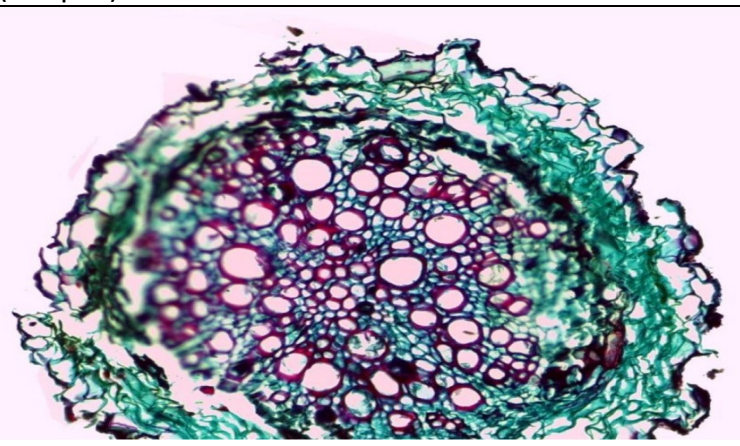

Fig. (11): Root section of pepper plants infected with $M$. incognita and treated with the nematicide Vydate

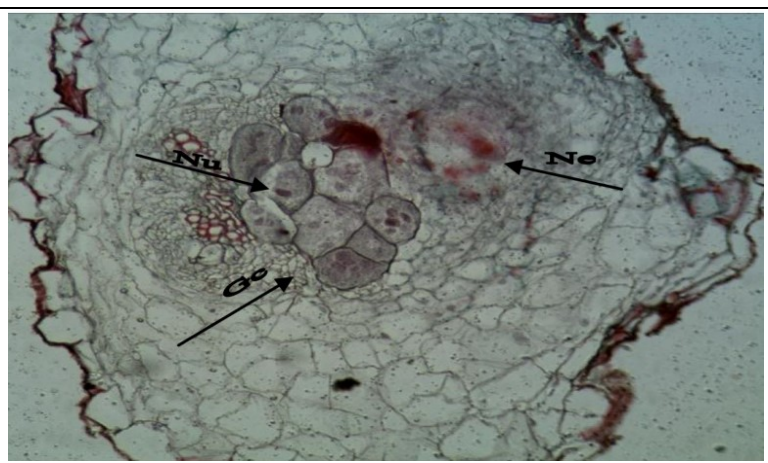

Fig. (6): Root transverse section of pepper plant infected with $M$. incognita and treated with SA $(300 \mu \mathrm{M})$.

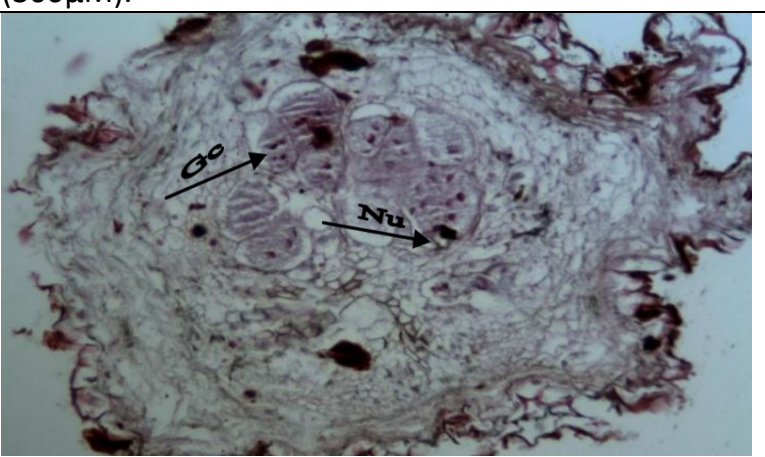

Fig. (8): Root transverse section of pepper plants infected with $M$. incognita and treated with IAA $(300 \mu \mathrm{M})$.

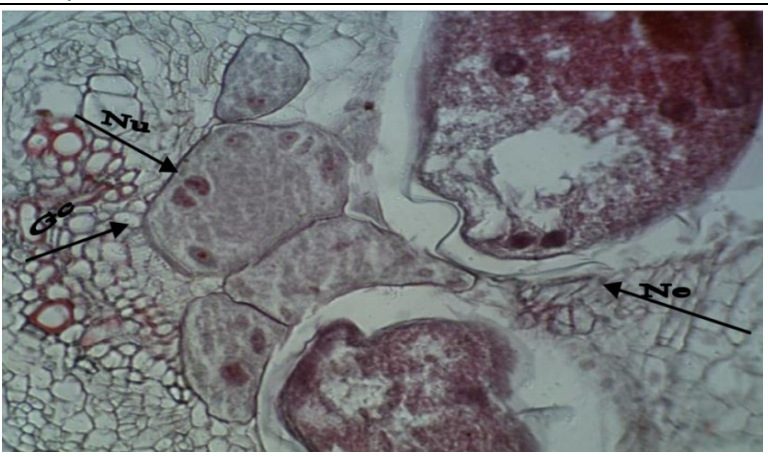

Fig.(10 ): Root transverse section of pepper plants infected with $M$. incognita and treated by the biofertilizer Halex-2 at 7g/L.

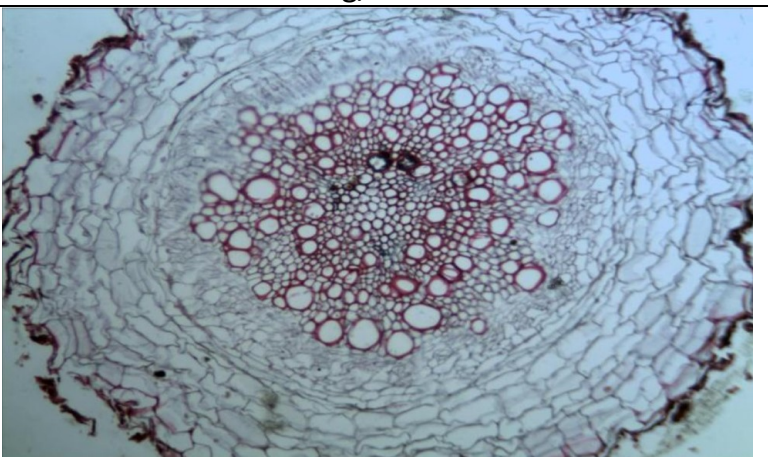

Fig.(12): Root section of healthy plant roots as a control 

Root knot nematodes induce giant cells as a feeding site. Vallad and Goodman (2004) showed that at least two forms of induced resistance, systemic acquired resistance (SAR) and induced systemic resistance (ISR) as distinct phenomena based on the type of inducing agents and host signaling pathways that result in resistance expression. Ethylene and auxin are important plant hormones involved in the regulation of many important plant processes. For instance, cell differentiation, cell expansion, and responses of plant to abiotic stresses (Davies, 2010). Moreover, these hormones play vital roles in many plant pathogen interactions, including manipulation of plant defense responses and development of symptoms. Ethylene induced plant resistance by genes activation. Meanwhile, plant hormones like Eth and JA have the ability to interfere with tomato SA inducible resistance pathway in susceptible cultivars. Thus, phytohormones involved in many processes of plant nematode parasitism like the involvement of invasion plant cell and induction of syncytium (Uehara et al., 2010).

Wang et al., (2007) reported that SA causes global repression of auxinrelated genes, which repress proteins and inhibit auxin response SA mediated disease resistance mechanism due to the inhibitory effect on auxin signaling.

Oka and Spiegel (1999) indicated that induced resistance can be local or systemic. Local induced resistance refers to cases where the response is local whereas systemic induced resistance describes resistance that is induced in a part of the plant that is specially separated from the point of induction. Although they differ, both local and systemic resistance requires some time to develop after application of the inducing treatment and both are non-specific in nature. (Hammerschmidt 1999) reported that reduced population growth of the pathogen in locally induced resistance may be due to the production of PR proteins (defensive plant proteins specifically induced in pathological or related situations) and cell wall alterations that prevent or inhibit growth and development of the pathogen as well as challenge pathogens. (Conrath et al.. 2002) described that resistanceactivating treatment in systemic resistance results in a change in cells at a distance from the induction site that allows rapid defense activation called priming.

Huang (1998) reported that plant defense mechanisms can be either preformed or induced only after the plant is attacked or otherwise injured. The general understanding is that plants can actively guard themselves and have induced resistance against virulent pathogens.

We document here a different tactic to reduce plant damage due to nematodes. Using novel inducers i.e., SA, IAA, JA, Eth and a biofertilizer, which have broad spectrum effects, including benefits to plant growth and enhancement of plant resistance. Programmed cell death (PCD) and hypersensitive response $(\mathrm{HR})$ are the main results of ROS (free radicals) signaling in plants (Jonathan et al., 2004). It has been reported that the production of ROS is one of the earliest events in molecular plant-nematode interaction (Grundler et al., 1997). R proteins frequently lead to the up regulation of genes involved in ROS production, which result in HR. Plants have a variety of antioxidant enzymes (e.g. peroxidase, catalase and polyphenoloxidase) to scavenge excessive ROS in plant tissue to 
prevent self-damage. Moreover, another enzyme; superoxide dismutase (SOD), detoxifies ROS produced by the plant cell and induces plant resistance (Bellafiore et al., 2008, Roze et al., 2008, and Ali et al., 2018).

Peroxidase represents a large group of oxidoreductases that catalyzes the oxidation of substrate molecules using hydrogen peroxide as electron acceptor. These enzymes play a key role in important biological processes, such as lignin degradation pathway and host defense mechanisms (Davies et al., 2008). Mostafenezhad et al. (2014) reported that treatment with $S A$ promoted the highest activity of peroxidase, 4 days after treatment. Catalase plays the role of a specific peroxidase protecting cell from toxic effects of $\mathrm{H} 2 \mathrm{O} 2$ (Ben Amor et al., 2005).

Devrajan and Srenivasan (2002)
reported that peroxidase and
polyphenoloxidase (catechol oxidase) were synthesized in the root of banana (Musa sp.) due to infection with $\mathrm{M}$. incognita. They also concluded that biochemical and molecular changes were associated with resistance reaction of banana against root-lesion incited by root-knot nematodes. Moreover, (Singh et al. 2013) reported that the accumulation of phenolic acid was also increased after nematode infection. (Patel et al. 2001) reported that Meloidogyne spp. have ability to induce synthesis of peroxidase, polyphenoloxidase and total phenols in roots of chickpea.

Our results indicated that the inducers used in our study significantly increased antioxidant enzymes i.e., peroxidase, polyphenoloxidase as well as catalase, which promoted synthesis of chemical components i.e., sugars and phenols, which reflected a good performance of pepper plants under nematode infection conditions.
According to the results of many authors, it is possible that phenolics play the main role: (i) Browning and slow formation of wide necrosis in plants susceptible to the migratory nematodes. (ii) Quick browning and formation of non-expandable necrosis in plants resistant to migratory parasites. (iii) IAA oxidase inhibition, which may favor auxin decomposition and formation of necrosis in plants resistant to nematodes.

Histological changes in pepper plant roots infected with root-knot nematode $M$. incognita as affected by the addition of some electors

Our investigation of histological alterations in pepper roots infected with $M$. incognita and treated with some electors revealed that SA $(300 \mu \mathrm{M})$ poorly induced formation of giant cells with limited hypertrophy. However, JA treatment incited less numbers of giant cells, little damage in cortex and xylem layers, and less number of hypertrophied giant cells. IAA at $300 \mu \mathrm{m}$ showed a good performance at the beginning; noticed as no formation of any giant cells. While Eth $(300 \mu \mathrm{M})$ treatment did not induce formation of any giant cells and the root section has no difference from the healthy control root section. The biofertilizer (Halex-2) treatment recorded less number of giant cells and irregular formation and disruption in xylem layer.

Glazer et al. (1983 \& 1985) reported that chemical blocking ethylene production inhibited gall development in tomato and that treatment of plants with Eth- precursor led to better giant cells enlargement. This is an important role of Eth-responses in activation of JAdependent defense against RNC (Nahas et al., 2011; Fudali et al., 2013). Eth probably plays different roles at different stages of the nematode infection process: having a restraining role by activating nematode repellents 
and JA biosynthesis, facilitating radial expansion of the giant cells. Auxin manipulation is well-known to be an important process during initiation and development of nematode feeding sites (NFS) of sedentary plant parasitic nematodes (Grunewald et al., 2009).

Saeed (2005) studied the anatomical alterations in roots of $M$. incognitainfected soybean plants due to application of some resistance inducers. He found that histological alterations in root tissue of soybean plants revealed normal appearance of the nematode, which succeeded in developing giant cells with normal shape, size and contents. Apparently, nematode status seemed to be normal inserting its head region in a cluster of normal giant cells, laying in stellar region, extending in cortical layer. At least six giant cells were noticed in close vicinity to the nematode frontal part and encircled with hyperplastic cells. Also, giant cells contained several darkly stained nuclei with prominent nuclei. Interestingly, no necrotic areas were found around or near the nematode or giant cells.

\section{CONCLUSION}

It can be concluded that $300 \mu \mathrm{M}$ of all inducers is the best concentration to controlling root knot nematode and preventing the formation of giant cells. It has a similar effect as the nematicide vydate and also increases the content of sugars, phenols and antioxidant enzymes activity. Moreover, ethylene at $300 \mu \mathrm{M}$ was the most effective in controlling $\mathrm{M}$. incognita in pepper plant. This novel and promising results may lead to a reduction of the use of nematicides, which are harmful to human and the environment. It can also help the plant breeders to create new resistant cultivars against $M$. incognita.

\section{REFERENCES}

Ali, M.A.; Abbas, A.; Kreil, D.P. and Bohlmann, $\mathrm{H}$.

(2013) Overexpression of the transcription factor RAP 2.6 leads to enhanced callus deposition in syncytia and enhanced resistance against the beet cyst nematode Heterodera schachtii in Arabidopsis roots. BMC Plant Biology 13: 1471-2229.

Aluko R. and Ogbadu G.H. (1986) Analysis of eggplant varieties for enzymes related to their organoleptic properties. Trop. Science. 26: 163171.

Amjad, A.M.; Anjam, M.S.; Nawaz, M.A.; Lam HonMing, and Gyuhwo Chung (2018) Signal transduction on plant nematode interaction. International. J. Molecular Science. 19, 1648: 2-18.

Bach, A.N. and Oparin, A.E. (1968) Determination of Catalase Activity Rasteni. 184-186 (Russ).

Bakr R.A. and Hewedy, O.A. (2018) Monitoring of Systemic Resistance Induction in Tomato Against Meloidogyne incognita. J. Plant Pathol. Microbiol 9: 464. doi:10.4172/2157-7471.1000464.

Bellafiore, S.; Shen, Z.X.; Rosse, M.M; Abad, P.; Briggs, S.P. (2008) Direct identification of the Meloidogyne incognita Secretom reveals proteins with host cell reprogramming potential. Plos Pathogenic. 4: 180192.

Ben Amor, N.; Ben Hameda, K.; Debega, A.; Grignonb C. and Abdelly, C. (2005) Physiological and antioxidant responses of the perennial halophyte acrithmum maritimum to salinity. Plant Science. 168: 889- 899.

Broesh, S. (1954) Colorimetric assay of phenoloxidase. Bull. Sac. Chem. Biol. 36: 711-713. 
Conrath, U.; Peiterse, C.M.J. and Mauch-Mani, B. (2002) Priming in plant-pathogen interactions. Trend in Plant Science 7: 210-216.

Cooper, W.R.; Jia, L. and Goggin, L. (2005) Effects of jasmonate induced defenses on root-knot nematode infection of resistant and susceptible tomato cultivars. Journal of Chemical Ecology 31(9): 1953-1967.

Costat Software (1985) User's Manual Version 3 CoHort. Tusson, Arizona, U.S.A

Davies, P.J. (2010) The plant hormones: their nature, occurrence, and functions. Plant Hormones, pp115.

Davies, M.J.; Ilawkins, C.L.; Pattison, D.I. and Rees, M.D. (2008) Mammalionheme peroxidases from molecular mechanisms to health implications. Antioxidants \& Redox Signaling 10: 1199-1234.

Devrajan, K.; and Srenivasn, N. (2002) Biochemical changes in banana roots due to Meloidogyne incognita infected with Paceilomyces lilacinus. Curr. Nematol. 13: 1-5.

Fehrman, H.; and Dimond, A.E. (1967) Peroxidase activity and Phytophthora resistance in different ranges of potato. Plant Pathology. 57: $69-72$.

Fudali, S.L.; Wang, C.L.; and Williamson, V.M. (2013) Ethylene signaling pathway modulates attractiveness of host roots to the root-knot nematode Meloidogyne hapla. Molecular Plant-Microbe Interactions 26: 75-8.

Glazer, I.; Orion, D.; and Apelbaum A. (1983) Interrelationships between ethylene production, gall formation, and root-knot nematode development in tomato plants infected with Meloidogyne javanica. Journal of Nematology. 15: 539-544.
Glazer, I.; Apelbaum, A. and Orion, D. (1985) Effect of inhibitors and stimulators of ethylene production on gall development in Meloidogyne javanica infected tomato roots. Journal of Nematology. 17: 145-149.

Godelieve, G. and Melissa, G.M. (2019) Phytoparasitic nematode control of Plant hormone pathways. Plant Physiology 4 (179):1212-1226.

Grundler, F.M.W.; Sobezak, M.M. and Lange (1997) Defense responses of arabidopsis thaliana during invasion and feeding site induction by the plant parasitic nematode Heterodera glycines. Physid Mol. Plant Pathology. 50: 419-429.

Grunewald, W.; Cannoot, B.; Friml, J.; and Gheysen, G. (2009) Parasitic nematodes modulate PIN-mediated auxin transport to facilitate infection. Plos pathogens 5(1): 260-266.

Hagag, Eman S.F.; Taha, N.A.A.; and Hafez, Y.M. (2016) Control of root knot nematode Meloidogyne incognita on eggplants using biotic and abiotic inducers of resistance. Egyptian Journal of Biological Pest Control, 26(2): 269-275.

Hammerschmidt, R. (1999) Induced disease resistance: How do induced plants stop pathogens? Physiological and Molecular Plant Pathology 55:77-84.

Hari, C.M.; Gajbhiye, V.T. and Singh, G. (2011) Salicylic acid-induced glutathione status in tomato crop resistance to root-knot nematode Meloidogyne incognita (kofoid and white) chitwood. Journal of Xenobiotic 1(1): 22-28.

Huang, J.S. (1998) Mechanisms of Resistance the Cyst Nematodes. Netherlands: Kluwer Academic Press. Pp. 353-368. 
Ibrahim, I.K. (2011) Nematode Pests

Parasites of Field Crops. Manshaat El. Maaref, Alexandria, 250pp.

Jonathan, P.A.; Ellet, B.K.S.; Peer, M.S.; John, M.M.; Olivia, J.D.; Christina, E.; Donald, J.M.; Pawl, R.E. and Kemal, K.C. (2004) Antagonistic interaction between abscisic acid and jasmonate. Ethylene signaling pathways modulates defense gene expression and disease resistances in Arabidopsis. The Plant Cell 16: 3460-3479.

Kazunori, O.; Hiroshi, A.; and Genichiro, A. (2015) Jasmonates induce both defense responses and communication in monocotyledonous and dicotyledonous plants. Plant Cell Physiology. 56(1): 16-27.

Kumari, C; Dutta, T.K.; Banakar, P.; Rao, U. (2016) Comparing the defense- related gene expression changes up on root-knot nematode attack in susceptible versus resistant cultivars of rice. Scientific Reports. 6 : 228-246.

Kyndt, T.; Nahar, K.; Haeck, A.; Verbeek, R.; Demeestere, K. and Gheysen, G. (2017) Interplay between carotenoids, abscisic acid and jasmonate guides the compatible rice-Meloidogyne graminicola interaction. Front Plant Sci. 8: 951.

Li, J.; Brader, G.; Kariola, T. and Tapio, E. (2006) WRKY 70 modulates the selection of signaling pathways in plant defense. Plant J. 46: 477-491.

Majda, M. and Robert, S. (2018) The role of auxin in cell wall expansion. International Journal of Molecular Sciences. 19: 951.

Mantelin, S.; Bhattarai, K.K.; Jhaveri, T.Z. and Kaloshian, I. (2013) Mi-1mediated resistance to Meloidogyne incognita in tomato may not rely on ethylene but hormone perception through ETR3 participates in limiting nematode infection in a susceptible host. Plos One 8(5): 1-8.

Mostafanezhad, H.; Navazollah, S. and Shaheen, N.Z. (2014) Control of root-knot nematode (Meloidogyne javanica) with combination of Arthrobotrys oligospora and salicylic acid and study of some plant defense responses. Journal of Crop Protection. 3 (4): 499-508.

Mur, L.A.J.; Kenton, P.; Atzorn, R.; Miersch, O.; Wasternack, C. (2006) The outcomes of concentrationspecific interactions between salicylate and jasmonate signaling include synergy, antagonism, and oxidative stress leading to cell death. Plant Physiol. 140: 249-262.

Nahar, K.; Kyndt, T.; Devleesschauwer, D.; Höfte, M. and Gheysen, G. (2011) The jasmonate pathway is a key player in systemically induced defense against root knot nematodes in rice. Plant Physiology. 157: 305-316.

Naserinasab, F.; Sahebani, N. and Etebarian, H.R. (2011) Biological control of Meloidogyne javanica by Trichoderma harzianum $\mathrm{BI}$ and salicylic acid on tomato. African Journal Food Science. 5(4): 276280.

Nina, K.; Radakovic, Z.; Regis, J.M.; Dobrev, P.; Vankova, R.; Grundler, F.M.; Siddique, S.; Hofmann, J. and Wieczorek, K. (2015) Role of stressrelated hormones in plant defense during early infection of the cyst nematode Heterodera schachtii in Arabidopsis. New Physiologist 207: 778-789.

O'Brien, T.P. and Mccully, M.E. (1981) The Study of Plants Structure, Principles and Selected Methods. 
Termarcarphipty.

Australia. 271pp.

Oka, C.Y. and Spiegel, Y. (1999) Local and systemic induced resistance to the root-knot nematode in tomato by DL-b-amino-n butyric acid. Phytopathol. 89: 1138-1143.

Patel, B.A.; Patel, D.J.; Patel, R.G. and Talati, J.G. (2001) Biochemical changes induced by infection of Meloidogyne spp. in chickpea. Intern. Chickpea Pigeonpea Newslett. 8: 13-14.

Roze, E.; Hanse, B.; Mitreva, M.; Vanhotme, B.O.; Bakkor, J. and Smaut, G. (2008) Mining the section of the root Knot nematode Meloidogyne chitwoodi for candidate parasitism genes. Molecular Plant Patholology. 9: 1-10.

Saeed, M.M. (2005) Utilization of some specific materials to stimulate resistance in some host plants against root knot nematodes. Ph.D. Thesis, Cairo Univ., Fac. Agric. 220pp.

Sahebani, N. and Hadavi, N. (2009) Induction of $\mathrm{H} 2 \mathrm{O} 2$ and related enzymes in tomato roots infected with root knot nematode $(M$. javanica) by several chemical and microbial elicitors. Biocontrol Science and Technology 19: 301313.

Sasser, J.N.; Carter, C.C. and Hartman, K.M. (1984) Standardization of host suitability studies and reporting of resistance to root knot nematode. Raleigh, North Carolina, United States of America pp.1-10.

Selim M.E., Mahdy M.E., Sorial M.E., Dababat A.A., Sikora R.A. (2014) Biological and chemical dependent systemic resistance and their significance for the control of root- knot nematodes. Nematolo 16: $917-$ 927.

Shukla, N.; Yadav, R.; Kaur, P.; Rasmussen, S.; Goel, S.; Agarwal, M.; Jagannath, A.; Gupta, R.; Kumar, A. (2018) Transcriptome analysis of root-knot nematode (Meloidogyne incognita)-infected tomato (Solanum Iycopersicum) roots reveals complex gene expression profiles and metabolic networks of both host and nematode during susceptible and resistance responses. Molecular Plant Pathology. 19: 615-633

Simons, T.J. and Ross, A.F. (1971) Changes in metabolism associated with enclosed systemic resistance to tobacco. Phytopathology. 61: 12611265.

Singh, A.; Ritesh, K.J.; Sudarshan, M. and Udai, P.S. (2013) Analysis of phenolic and indole acetic acids in Meloidogyne sp. infected rice plants (Oryza sativa L.). International Journal Advanced Research 1(6): 71-76.

Snedecor, W. and Cochran, W.G. (1972) Statistical Methods. 6th Edition. The lowa State College Press. lowa, U.S.A.

Thomas, W. and Dutcher R.A. (1924) The determination of carbohydrate in plants by picric acid reduction method. The estimation of reducing sugar and sucrose. J. Am. Chem. Soc. 46: 1662-1669.

Uehara, T.; Suglyama, S.; Matsuwsa, H.; Arie, T. and Masuta, C. (2010) Resistant and susceptible responses in tomato to cyst nematode are deferentially regulated by salicylic acid. Plant Cell Physiol. 51: 15241536.

Vallad, G.E. and Goodman, R.M. (2004) Systemic acquired resistance and induced systemic resistance in 
conventional agriculture. Crop Science 44: 1920-1934.

Wang, D.; PaJerowska-Mukhtar, K.; Cullen A.H. and Dang, X. (2007) Salicylic acid inhibits pathogen growth in plants through repression of the auxin signaling pathway. Curr. Biol. 17: 1784-1790.

Wubben, M.J.E.; Jin, J. and Baum, J.J. (2007) Cyst nematode parasitism of Arabidopsis thaliana is inhibited by salicylic acid (SA) and elicits uncoupled SA independent pathogenesis' related gene expression in roots. Molecular PlantMicrobe Interact. 21(4): 24-43.

Yuan, J.; Bateman, P. and GutierrezMarcos, J. (2016) Genetic and epigenetic control of transfer cell development in plants. Journal of Genetic and Genomics 43: 533-539.

Zhao, W.; Li, Z.; Fan, J.; Hu, C.; Yang, R.; Qi, X.; Chen, H.; Zhao, F. and Wang, S. (2015) Identification of jasmonic acid-associated microRNAs and characterization of the regulatory roles of the miR319/TCP4 module under rootknot nematode stress in tomato. Journal of Experimental Botany. 66: 4653-4667

Zebire, D.A. (2017) Role of phytohormones (indol acetic acid, Jasmonic acid, salicylic acid, and ethylene) in nematode plant interactions. African journal of Agricultural Research 12(19): 16121617. 